\title{
Understory and Soil Macrofauna Diversity under the Three Young Native Species and Acacia crassicarpa in a Drained Peatland of Pelalawan-Riau, Indonesia
}

\author{
Avry Pribadi ${ }^{1}$ and Ahmad Junaedi $^{1}$ \\ ${ }^{1}$ Balai Litbang Teknologi Serat Tanaman Hutan, Riau 28401, Indonesia
}

\begin{abstract}
Most studies mentioned that Acacia crassicarpa belongs to invasive species that could threat the native biodiversity. To respond that issue, we conducted a study that covers the understory and soil macrofauna diversity of three native tree species, namely mahang (Macaranga pruinosa), skubung (Macaranga gigantea) and geronggang (Cratoxylum arborescens) and an exotic species namely krassikarpa in a drained peatland in Pelalawan, Riau. The observation of understory vegetation under each studied species was undertaken by using $2 \times 1 \mathrm{~m}$ plots. Furthermore, the structure of macrofauna was observed by pitfall trap methods. Results revealed that there were two fern species namely Neprolephis biserrata and Stenochlaena palustris that dominated the understory vegetation in namely mahang (Macaranga pruinosa), skubung (Macaranga gigantea) and geronggang (Cratoxylum arborescens). The diversity index in vegetation structure among those four tree species was insignificantly varied. Moreover, the percentage of understory coverage under A. crassicarpa was significantly higher than that under all native tree species. On the other hand, Formicidae and Rhinotermitidae were dominant in skubung and krassikarpa. Meanwhile, Formicidae and Blattidae were high in mahang and geronggang. Furthermore, diversity index of macrofauna were significantly low at krassikarpas`s understory compare to other three native species. This study suggested that the introduction of krassikarpa affect the biodiversity.
\end{abstract}

Keywords: Mahang, skubung, geronggang, krassikarpa, understory and soil macrofauna

\section{Introduction}

Indonesia is the second largest biodiversity country in the world after Brazil [1,2]. In order to maintain its biodiversity richness, Indonesia established 566 national parks that almost protecting 36 million ha [3]. Furthermore, Indonesia has at least 88 million ha, including tropical peat swamp forests that are about 21 million ha of this type of tropical forest in Kalimantan, and Papua were disturbed [4,5]. Peat is one of soil type which has more than $18 \%$ of C-content and commonly found in one ecosystem located behind the riverbank [5,6]. One characteristic of peatland is that the land is easily and rapidly loss their water content and it leads to desiccation [7]. When the desiccation is widely and heavily spreading, it is easily being burned and would lead to more disastrous situation.

Besides its vulnerable characteristics, biodiversity loss is the other problems which are more challenging in peatland. Forest degradation and conversion into agriculture purposes, unsustainable and irreversible forest management, expanding of infra structure, slash and burn, and illegal mining, has been blamed for biodiversity loss in peatland [5,8-11]. Yet, another challenge is coming from the introduction of alien species that could threat our native 
species and biodiversity. There are many studies mentioned about existence of Acacia species which is sometimes called as invasive species that was harmfulfor native species since it has characteristic as invasive species [12-15] . In Riau province, one of exotic Acacia species i.e. A. crassicarpa (krassikarpa) has been commonly grown in peatland by two biggest pulp and paper industries (APRIL and APP Sinar Mas). In addition, A. crassicarpa was originally distributed in Australia and south Papua [16] .

The existence of $A$. crassicarpa in Riau province gives positive impacts in social and economy side. Nonetheless, there is no many studies that concern in biodiversity structure changing formed by the existence of $A$. crassicarpa. Thus, study that reveals the effect of $A$. crassicarpa`s existence needs to be conducted. The most common methods to answer the questions is by doing a comparative study that comparing macrofauna and understory vegetation of the exotic tree species (A. crassicarpa) and local native trees species (M. gigantea, M.pruinosa, and C. arborescens).

Understory vegetation is one of biodiversity group that not only have responsibility in soil and waterconservation but in erosion preventing also $[17,18]$. Furthermore, according to Lisnawati et al. [6] soil fauna holds the important role in restoring physics, chemistry, and biology structure through immobilization and humification. As a result, their existence has been considered as soil quality bioindicator [6,19]. Hence, based on those problems and issues, the objective needs to be addressed in this study was to examine the structure and diversity of understory and macrofauna between exotic tree species and three native trees species.

\section{Material and methods}

\subsection{Study site and time}

This study was conducted in a drained peatland at Lubuk Ogong, Pelalawan regency, Riau province (101 '41'06"$101^{\circ} 41^{\prime} 10^{\prime \prime}$ E, ${ }^{00} 19^{\prime} 42^{\prime \prime}-0^{\circ} 19^{\prime} 48^{\prime \prime} \mathrm{N}$ and $12 \mathrm{~m}$ asl) during March 2014 to December 2014. The peat type at location based on its maturity is dominated by fibric-hemic and drained with the annualvariation of water table depth was 20 - $140 \mathrm{~cm}$ below soil surface [20,21] .The plots were consisted of four years old of A. crassicarpa, M. gigantea, M. pruinosa, and C. arborescens.

\subsection{Design of observations}

In the beginning, the plots were established in 2011 by using Randomized Complete Block Design (RCBD) thus it was three years old already when this study was conducted. The plots were originally designed for silviculture intensive treatments. There were four tree species planted in the plots and each tree species had five replications. Every replication had $400 \mathrm{~m}^{2}$ and been planted with $3 \times 2 \mathrm{~m}$ of those four tree species.

\subsection{Sample collections}

Understory samples were collected by arranging five rectangles of $2 \times 1 \mathrm{~m}$ that were set in every plot of tree species (A. crassicarpa, M. gigantea, M. pruinosa, and C. arborescens). Plots were determined by systemic random sampling following diagonal formation of plots` size. Moreover, five replications were conducted for each species. Thus, we had 25 plots for each tree species. Vegetations were analyzed up to species level.

Macrofauna samples were collected by pitfall trap method. There were three traps that were set for each tree species. The traps were determined by systemic random sampling following diagonalformation of plots` size so that we had 15 traps for each tree species. Macrofauna were analyzed up to family level based on book Study of Insects written by Charles A. Triplehorn, Norman F. Johnson, and Donald Joyce Borror. 


\subsection{Data preparation and analysis}

The collected data was tabulated systematically in order to obtain the result of Important Value Index (IVI) of the understory vegetations and macrofauna. This data is important to determine the most dominant species that available in the plots. IVI was approached by determining the value of relative frequency (RF) percentage that was added by relative density (RD) percentage. Furthermore, the value of diversity index was determined using Shanon-Wiener equation (Odum, 1993).

$$
\begin{aligned}
& \mathrm{H}=-\Sigma\{(\mathrm{n} . \mathrm{i} / \mathrm{N}) \ln (\mathrm{n} . \mathrm{i} / \mathrm{N})\} \\
& \mathrm{H}^{\prime}=\text { diversity index } \\
& \mathrm{n} . \mathrm{i}=\text { important value of } \mathrm{N} \text { species } \\
& \mathrm{N}=\text { totalof important value }
\end{aligned}
$$

Furthermore, the data of IVI of understory and macrofauna was analyzed by descriptive qua ntita tive to figure out the most dominant species that occupied the understory and its structure. Meanwhile, anova was used to determine the tree species that had most significant value of understory and macrofauna diversity index. Tukey test was performed when anova`s result showed any significant results.

\section{Results and discusions}

\subsection{Understory vegetation}

In general, number and diversity species within a community describe a picture of the richness and diversity of its community. Meanwhile, species domination is the sign of special entity of the community. The results revealed that ferns species, namely Neprolephis biserrata and Stenochlaena palustris dominated the understory vegetation understands of $M$. gigantea, $M$. pruinosa, and $C$. arborescens. Yet, $N$. biserrata was more dominant than S. palustris in all three native species (Table 1). Similarly, in exotic tree species (A. crassicarpa), N.biserrata and S. palustris became the most dominant vegetation that occupied A. crassicarpa's understory. Moreover, N. biserrata had four times of IVI than S. palustris (Table 1). Interestingly, the second largest group that dominated the three native tree species and the exotic species were varied. In M. gigantea and M. pruinosa, narrow leaf weed is dominant than broad leaf weed. Even Scleria sumatrensis and Ottochloa spinosa were two species found dominant after ferns in $M$. gigantea. In contrast, $C$. arborescens did not have any narrow leaf weed in its understory and were dominantly

\begin{tabular}{|c|c|c|c|c|c|}
\hline \multirow[b]{2}{*}{ Species } & \multirow[b]{2}{*}{ Family } & \multicolumn{4}{|c|}{ Important Value Index } \\
\hline & & $\begin{array}{c}M . \\
\text { gigantea }\end{array}$ & M. pruinosa & C. arborescens & A. crassicarpa \\
\hline Nephrolepis biserrata & Nephrolepidaceae & 25.39 & 25.99 & 26.34 & 52.05 \\
\hline Stenochlaena palustris & Blechnaceae & 14.68 & 13.32 & 22.69 & 12.61 \\
\hline Asystasia sp. & Acanthaceae & 3.94 & & & 3.73 \\
\hline Melastoma malabatrichum & Melastomaceae & 3.94 & 6.76 & 11.74 & \\
\hline Scleria sumatrensis & Cyperaceae & 13.96 & 11.20 & & 3.73 \\
\hline Ottochloa spinosa & Poaceae & 4.65 & & & \\
\hline $\begin{array}{l}\text { Seedlings and saplings of } \\
\text { Acacia crassicarpa }\end{array}$ & Fabaceae & 3.94 & & & 9.58 \\
\hline Colopogonium sp. & Fabaceae & & 8.88 & 3.67 & \\
\hline Mikania micrantha & Asteraceae & & 3.73 & & \\
\hline Smilax sp. & Smilacaceae & & & & 3.73 \\
\hline
\end{tabular}
occupied by broad leaf weed named Melastoma malabatrichum. Meanwhile, seedlings and saplings of A. crassicarpa were dominant in its understory afterferns.

Table 1. IVI of understory`s vegetation of A. crassicarpa, M. gigantea, M. pruinosa, and C. arborescens. 
Pterydophyta division was the vegetation that dominantly occupied the understory structure of under all trees species either in native or exotic trees species. S. palustris and $N$. biserrata were two species of ferns that dominated vegetation structure. Moreover, besides Dicranopteris sp. and Blechnum orientale, S. palustris and N. biserrata are two species of ferns that dominantly covered the floor of A. crassicarpa planted in peat land [22-24]. A study conducted by Harnelly et al. [24] revealed that N. biserrata, B. orientale, and Pteris trimula that are classified as fern, dominantly grew at the Rawa Tripa Peat Swamp Forest, Aceh. It means that those species were highly adaptive not only at native trees species but at exotic tree species also. Furthermore, N. bisserata had a tendency and prefer an area that was not inhabited by trees and rapidly cover post burned area [4,5]. In other words, A. crassicarpa had more level of light penetration compare to other native tress species. As a result, the IVI of $N$. biserrata at $A$. crassicarpa had IVI fourtimes was doubled than IVI of other native trees species. Thus, it is assumed that the condition under $A$. crassicarpa was suitable for $N$. biserrata to grow and develop.

The interesting facts occurred in the second group that dominated the floor of those exotic an d native trees species. Narrow leaf group were dominantly occupied at $M$. gigantea and $M$. pruinose that was represented by $S$. sumatrensis and $O$. spinosa. In contrast, $M$. malabatrichum that categorized as broad leaf group was the second dominant species at $C$. arborescens. Meanwhile, seedlings and saplings of $A$. crassicarpa were the second species that were highly found in A. crassicarpa's floor afterferns. Narrow leaf group abundancies were high when area was exposed to light penetration, particularly in the first year of $A$. crassicarpa and significantly decline when age of $A$. crassicarpa incline [22]. Other studies mentioned that spacing and grass weed (narrow leaf) has ability to inhibit the development of broad leaf seeds [26,27]. Meanwhile, there is no narrow leaf group could be found at C. arborecens`s understory and even $M$ malabatrichum which is a broad leaf that dominated the floor. $C$. arborescens has wider and denser canopy than $M$. pruinosa, $M$. gigantea, and A. crassicarpa. It reveals that broad leaf are more resistant than narrow leaf in case of low light penetration. When this phenomenon is compared to A. crassicarpa`s understory that is occupied by seedlings and saplings of $A$. crassicarpa, we assumed that the condition formed by A. crassicarpa is only suitable for ferns and not suitable for other local or native weeds, such as $S$. sumatrensis and M. malabatrichum. A report already stated that A. crassicarpa belongs to invasive species even though it was restricted in certain location [28] and its sister, Acacia mangium, has been grouped into invasive species also [29]. Hence, seedlings and saplings of $A$. crassicarpa are the second most species that could determine the understory afterferns.

Furthermore, the density or percentage of understory coverage area was sign ificantly high in A. crassicarpa than other native trees species $(\mathrm{p}<0.05)$. Interestingly, the percentage of understory`s covera ge area in $A$. crassicarpa was $100 \%$. In other words, the understory under A. crassicarpa was fully covered by vegetations which wa s dominantly condensed by ferns (Table 2). In contrast, the other three native trees species had a low percentage of understory`s coverage area $(<30 \%)$ (Table 2$)$.

Table 2. Percentage of understory coverage area of A. crassicarpa, M. gigantea, M. pruinosa, and C. arborescens.

\begin{tabular}{lc}
\hline \multicolumn{1}{c}{ Species } & Percentage of understory coverage area \\
\hline M. gigantea & $29.45 \pm 6.73 \mathrm{a}$ \\
M. pruinosa & $24.45 \pm 13.47 \mathrm{a}$ \\
C. arborescens & $27.77 \pm 10.71 \mathrm{a}$ \\
A. crassicarpa & $100 \mathrm{~b}$ \\
\hline
\end{tabular}

Remark: the alphabets appear after the value showed a significant value $(\mathrm{p}<0.05)$.

In addition, percentage of understory coverage was significantly high and $100 \%$ fully covered the floor of $A$. crassicarpa than any other native trees species. When this data was combined to IVI that placed ferns as the most dominant species, it could be assumed that the condition is appropriate for ferns growth and development. The first factor that could determine this phenomenon is the interaction between genetics and environment, such as soil, microclimate, microorganism, and competition with other species [9,10]. Secondly, the ability of the species to propagate themselves [10,11]. Moreover, most ferns grow well in 40\%-50\% of light penetration, $60 \%-80 \%$ of humidity (to inhibit desiccation), temperature of $21^{\circ} \mathrm{C}-27^{\circ} \mathrm{C}$, and attach themselves into humid soil [32] . Moreover, 
Kerb [33] stated that the capability of certain species to occupy an area is influenced not only by its ability in establishing the adaptation mechanism toward all abiotic factors, such as temperature, light, soil, humidity, etc. and biotic factors, such as intra species interaction, competition, parasitism, etc. but also chemistry factors that include water, oxygen, $\mathrm{pH}$, and nutrition. Hence, it could be assumed that condition under A. crassicarpa is appropriate for ferns. In the opposite, the phenomenon at three native trees species that only coverage under $30 \%$ of its floor showed that the environment condition created by those three native trees species are not favorable and tend to inhibit the development and growth of understory vegetation.

Besides, the diversity index value of $A$. crassicarpa and other three native trees species revealed that there were no significant differences ( $>0.05$ ). It means that the diversity index of those species was statistically similar (Table 3). Nonetheless, A. crassicarpa had the lowest diversity index value than the other all native tree species. Moreover, M. gigantea had the highest value of diversity index and three times of diversity index value of A. crassicarpa.

Table 3. Diversity index of understory`s vegetation of A. crassicarpa, M. gigantea, M. pruinosa, and C. arborescens.

\begin{tabular}{lc}
\hline \multicolumn{1}{c}{ Species } & Diversity index (shanon-weiner) \\
\hline M. gigantea & $1.80 \pm 0.47 \mathrm{a}$ \\
M. pruinosa & $1.13 \pm 1.03 \mathrm{a}$ \\
C. arborescens & $0.98 \pm 0.31 \mathrm{a}$ \\
A. crassicarpa & $0.61 \pm 0.08 \mathrm{a}$ \\
\hline
\end{tabular}

Remark: the alphabets appear after the value showed a significant value $(\mathrm{p}<0.05)$

Diversity index analysis showed that there was no significant between three native trees species and exotic tree species ( $>0.05$ ). Thus, it means that diversity index between all tree species is similar. Nonetheless, A. crassicarpa`s understory had the lowest diversity index than other three native trees species. Even though floor of A. crassicarpa was fully and dominantly covered by ferns, the diversity index was low. This results was similar to a study conducted by Bela et al. [34] that revealed that diversity index of an peat land area that were dominated by fern (Dicranopteris linearis) was 0.3 . Hence, we assumed that ferns successes in occupying all the resources and do not give any opportunity for other seedlings and saplings to grow and develop. As a result, there was not many of seedling and sapling varieties that could compete and grow between ferns` domination. This a ssumption was supported by Jackson and Finley [35] that found at least two ways of ferns in inhibiting seedling germination, namely allelopathy and less light intensity (below 0.5 percent of full sunlight). Consequently, the seedlin gs and saplings of other species cannot be germinated and there was not much variation of species.

\subsection{Macrofauna}

The results revealed that Formicidae is family that dominated the floor of either exotic tree species or the three native tree species ferns species (Table 4). Compare to other families, Formicidae had five different groups than other families. Moreover, class of collembola was dominantly found in A. crassicarpa than other three native tree species observed. In addition to that, Rhinotermidae was the second largest family found in A. crassicarpa and M. gigantea. Meanwhile, bug family (Curculionidae) and Polydesmidae were the second largest family found in M. pruinosa. In C. arborescens, Blattidae was a family dominantly found after Formicidae. Interestingly, group of macrofauna that dominated all the four tree species either exotic tree species or native trees species belong to social insects, such as Formicidae and Rhinotermidae.

In macrofauna, Formicidae, which is represented by Formicidae, was the dominant family that occupied either exotic tree species or all three native trees species. Meanwhile, Rhinotermidae was the second largest family after Formicidae. Formicidae and termites are two groups of soil fauna that dominantly inhibit peat soil [36-38]. Formicidae are a group of insects that is commonly distributed almost in everyplace and have characteristics to adapt in varies types of peat soil [6] . Even, compare to other insects group, Formicidae are the most success group [39]. The ability of Formicidae to dominate ecosystem is supported by their characteristics as carnivore, saprophyte, predator, and 
detritivore. Formicidae has potency as a bioindicator of peat soil quality since they are ab le to live in an area that has wider range of $\mathrm{pH}$, soil humidity, and peat land types. Interestingly, A. crassicarpa had only two groups of Formicidae than other native trees species. According to Lisnawati et. al. [6], the number of formicidae describes soil humidity since Formicidae prefers to live in soil that have low in humidity. Hence, it can be inferred that soil humidity is higher in A. crassicarpa than other native trees species.

Table 4. IVI of soil macrofauna of A. crassicarpa, M. gigantea, M. pruinosa, and C. arborescens.

\begin{tabular}{|c|c|c|c|c|}
\hline \multirow{2}{*}{ Family / Class } & \multicolumn{4}{|c|}{ Important Value Index } \\
\hline & M. gigantea & M. pruinosa & C. arborescens & A. crassicarpa \\
\hline Formicidae 1 & 32.8 & 39.68 & 6.43 & 52.94 \\
\hline Formicidae 2 & 29.37 & 31.01 & 3.81 & 55.71 \\
\hline Formicidae 3 & & 9.61 & 10.37 & \\
\hline Formicidae 4 & 30.28 & 44.24 & 39.91 & \\
\hline Formicidae 5 & & & 30.98 & \\
\hline Curculionidae & 24.04 & 16.1 & 11.55 & 5.04 \\
\hline Carabidae 1 & 17.8 & & 8.93 & 5.4 \\
\hline Carabidae 2 & & & & 5.4 \\
\hline Blatidae1 & 17.8 & 36.31 & 30.98 & 22.38 \\
\hline Blatidae 2 & 23.14 & & 24.42 & \\
\hline Blatidae 3 & & & 6.43 & \\
\hline Polydesmidae & 11.57 & 16.35 & & 25.08 \\
\hline Rhinotermidae & 29.37 & 21.15 & & 77.22 \\
\hline Arachnida 1 & & 4.81 & 11.43 & \\
\hline Arachnida 2 & & 9.61 & & \\
\hline Gryllidae & & 6.49 & & \\
\hline Sapygidae & & & 6.43 & \\
\hline Theriidae & & & & 21.98 \\
\hline Melolonthidae & & & & 14.21 \\
\hline Coicidae & & & & 16.59 \\
\hline Collembola & 6.24 & 12.98 & 18.11 & 29.37 \\
\hline
\end{tabular}

The second dominant group was Rhinotermidae and only be found in A. crassicarpa, M. pruinosa, and M. gigantea. This result was supported study that mentioned that the number of Rhinotermidae increases in peat land but decreases in mineral land and in contrast, the number of Termitidae enhance in mineral land but decline in peat land $[40,41]$. Together with Formicidae, this termite makes tunnels within the ground which increase the porosity and room for plant's root to penetrate the soil so that these two groups could be used as bioindicator. Another factor that leads the abundance of Formicidae is the availability organic materials, such as wood. Wood is the main resources for Rhinotermidae for food and shelters [37]. In addition, the highest number of Rhinotermidae found at $A$. crassicarpa supported a study conducted by Haneda et. al. [40] and Kirton et. al. [42] that showed termites were the main pests in A. crassicarpa and A. mangium. Yet as it turns out, no Rhinotermidae collected at $C$. arborescensis presumably caused by lack of resources could be gathered under the stands. Moreover, a study conducted by Daviyana et.al. [43] stated that the extracts secreted from $C$. arborescens contain substances that control termites. In other words, inappropriate condition, which is harmfulfor termite, becomes limited factors for termite to live under C. arborescens.

In addition, it turns out that there was significantly different between diversity index value exotic tree species $(A$. crassicarpa) to other three native trees species ( $p>0.05$ ) (Table 5). Those native trees species had diversity index more than 2 and it means that the diversity level of those three native tree species was categorized as medium. In contrast, A. crassicarpa had the lowest diversity index value which valued 0.57 and was categorized as low. One thing that is interesting was the number of subclass collembola which was dominant at A. crassicarpa. Many studies reported that under dense canopy, high humidity, and thick litter, population of collembola wa highly found $[6,44,45]$. In contra st, the population decline in open area which is heavily exposed to light $[44,46]$. Hence, it could be inferred that soil condition, such as humidity and litter thickness, formed by A. crassicarpa was more suitable for collembola to live compare to other native trees, particularly $M$. gigantea. Those studies also supported the result which found that the 
lowest number of collembola was in M. gigantea. Based on observation, condition of M. gigantea `s floor was relatively clear from litter and was heavily exposed to sun light penetration compare to A. crassicarpa.

Table 5. Diversity index of understory`s vegetation of A. crassicarpa, M. gigantea, M. pruinosa, and C. arborescens.

\begin{tabular}{lc}
\hline \multicolumn{1}{c}{ Species } & Diversity index (shanon-weiner) \\
\hline M. gigantea & $2.12 \pm 0.01 \mathrm{a}$ \\
M. pruinosa & $2.22 \pm 0.18 \mathrm{a}$ \\
C. arborescens & $2.13 \pm 0.18 \mathrm{a}$ \\
A. crassicarpa & $0.57 \pm 0.11 \mathrm{~b}$ \\
\hline
\end{tabular}

Remark: the alphabets appear after the value showed a significant value $(\mathrm{p}<0.05)$

Analysis of variance of macrofauna`s diversity showed that diversity index level at A. crassicarpa was significantly low than any other three native trees species $(\mathrm{p}<0.05)$. Moreover, the diversity index was categorized low at A. crassicarpa. Meanwhile, diversity index was categorized as moderate at other three native trees species. This result was different to a study conducted by Handayani and Winara [37] that showed that diversity index at secondary forest of $A$. crassicarpa was at moderate level $\left(\mathrm{H}^{`}=2.09\right)$ and the lowest was at oil palm plantation $\left(\mathrm{H}^{`}=\right.$ 0.73). The value of diversity index at A. crassicarpa was similar to after-burned peat land di Riau [47] . Nevertheless, this result showed that there is transition and changing of macrofauna diversity level that could be seen from the differences of macrofauna`s diversity level at three native trees species and exotic tree species.

\section{Conclusions}

Neprolephis biserrata and Stenochlaenapalustris dominated the understory vegetation in A. crassicarpa, M. gigantea, $M$. pruinosa, and $C$. arborescens. Meanwhile, narrow and broad leaves group dominantly varied between $A$. crassicarpa, M. gigantea, $M$. pruinosa, and $C$. arborescens. The diversity index in vegetation structure among those four tree species was not significant. Yet, A. crassicarpa had the lower value of diversity index. Moreover, the percentage of understory coverage under A. crassicarpa was significantly higher than that under all native tree species. On the other hand, formicidae and rhinotermitidae were dominant in M. gigantea and A. crassicarpa. Meanwhile, formicidae and blattidae were high in M. pruinosa and C. arborescens. Furthermore, diversity index of macrofauna were significantly low at krassikarpas`s compare to other three native trees species. This study informed that the introduction of krassikarpa give significant effect on the level of the understory`s macrofauna biodiversity.

\section{References}

1. Von Rintelen K, Arida E, and HäuserC. A review of biodiversity-related issues and challenges in megadiverse Indonesia and other Southeast Asian countries. Res Ideas Outcomes. 2017 Sep;3:e20860.

2. Convention on Biological Diversity. Biodiversity facts; status and trends of biodive rsity, including benefits from biodiversity and ecosystem services. Indonesia - Main Details. 2020.

3. Dirjen KSDAE. Statistik Dirjen KSDAE. Jakarta: Kementerian Lingkungan Hidup dan Kehutanan; 2017.

4. Wahyunto, Ritung S, Suparto, and Subagjo H. Peatland distribution and its content in Sumatra and Kalimantan. Bogor; 2005.

5. Agus F, June T, Komara H, Syahbuddin H, Runtunuwu E, dan SusantiE. Mitigasi dan adaptasi perubahan iklim dari lahan perkebunan. Bogor; 2008.

6. Lisnawati Y, Suprijo H, dan Poedjirahajoe E. Hubungan kedekatan ekologis antara fauna tanah dengan karakteristik tanah gambut yang didraina se untuk HTI Acacia crassicarpa .J. Manusia dan Linghkungan. 2014;21(2):170-8.

7. Ariyanto DP, Sumarno, Supriyono, Yunus A, Pudjiasmanto B, and Rahayu. The productivity increa sing of peatlands on community land by multi-cropping model in Riau Indonesia. IOP Conf Ser Earth Environ Sci. 2019;393(1).

8. Hasanah A and Setiawan MF. Rewetting design for tropical peatland restoration. Sociae Polites. 2020;21(2):111-25. 
9. Hergoualc'h K, Atmadja S, Carmenta R, Martius C, Murdiyarso D, and Purnomo H. Managing peatlands in Indonesia: Challenges and opportunities for local and global communities. 2017.

10. Chin SY and Parish F. Peatlands: Status, challenges and actions in Southeast Asia. ASEAN Biodiverisity. 2013 Jan; 10.

11. Austin KG, Schwantes A, Gu Y, and Kasibhatla PS. What causes deforestation in Indonesia? Environ Res Lett. 2019;14(2). Sunardi S, Sulistijorini S, and Setyawati. T. Invasion of Acacia decurrens willd after eruption of Mount Merapi, Indonesia. Biotropia (Bogor). 2017 Jan;24:35-46.

12. Sunardi S, Sulistijorini S, and Setya wati. T. Invasion of Acacia decurrens willd after eruption of Mount Merapi, Indonesia. Biotropia (Bogor). 2017 Jan;24:35-46.

13. Montesinos D, Castro S, and Rodríguez-Echeverría S. Two inva sive acacia species secure generalist pollinators in invaded communities. Acta Oecologica. $2016 \mathrm{Jul} ; 74$ :In press.

14. Sutedjo S dan Warsudi W. Menakarsifat invasif spesies akasia mangium (Acacia mangium willd.) di hutan penelitian dan pendidikan bukit soeharto. J Hutan Trop. 2017;1(1):82-9.

15. Djufri. Pengaruh tegakan akasia (Acacia nilotica) (1.) willd. ex. del. terhadap komposisidan keanekaragaman tumbuhan bawah disavana Balanan Taman Nasional Baluran Jawa Timur. J Biol Edukasi. 2011;3(2):38-50.

16. Doran C.J. Australian trees and shrubs: species for land rehabilitation and farm planting in the tropics. Canberra; 1997.

17. Nikmah N, Wiryani E. Struktur komposisi tumbuhan bawah tegakan jatidikebun benih klon (kbk) Padangan Bojonegoro. J Biol. 2016;5(1):30-8.

18. IndriyaniL, Flamin A, dan Erna. Analisis keanekaragaman jenis tumbuhan bawah dihutan lindung jompi (Kelurahan Wali Kecamatan Watopute Kabupatenmuna Sula wesi Tenggara). Ecogreen. 2017;3(1):49-58.

19. Nahmani J, Lavelle P, dan Rossi JP. Does changing the taxonomical resolution alter the value of soil macro invertebrate as bioindikators of metal pollution? Soil Biol Biochem. 2006;38:385-396.

20. Junaedi A. Growth performance of three native tree species for pulpwood plantation in drained peatland of Pelalawan District, Riau. Indones J For Res. 2018;5(2):119-32.

21. Husnain H, Wigena IGP, Dariah A, Marwanto S, Setyanto P, and Agus F. CO2 emissions from tropical drained peat in Sumatra, Indonesia. Mitig Adapt Strateg Glob Chang. 2014;19(6):845-62.

22. Pribadi A dan Anggraeni I. Jenis dan struktur gulma pada tegakan Acacia crassicarpa dilahan gambut. Tekno Hutan Tanam. 2010;4(1):33-40.

23. Supangat A., Pribadi A, Kosa sih, dan Simatupang AD. Penga ruh pembangunan hutan tanaman terhadap biodiversitas. Laporan Hasil Penelitian BPHPS Kuok. Bangkinang; 2009.

24. Thomy Z, Masykur, and Yasmin Y. Diversity of plant species in Tripa Peat Swamp Forest, Aceh. In: Abs Sem Nas Masy Biodiv Indonesia.2016. p. 89-131.

25. Giesen W and Sari ENN. Tropical peatland restoration report : the Indonesian case tropical peatland restoration report : The Indonesian Case Berbak Green Prosperity Partnership/Kemitraan Kesejathera an Hijau (Kehijau Berbak). 2018;(3):99.

26. Daramola OS, Adeyemi OR, Adigun JA, and Adejuyigbe CO. Influence of row spacing and weed control methods on weed population dynamics in soybean (Glycine max L.). Int J Pest Manag. 2020;0(0):1-16.

27. Mirmanto E. Vegetation analyses of Sebangau peat swamp forest, Central Kalimantan. Biodiversitas J Biol Divers. 2009;11(2):82-8.

28. InternationalC. Invasive Species Compendium. Acacia crassicarpa (northern wattle). 2021.

29. JambulR, Limin A, Ali AN, and Slik F. Invasive Acacia mangium dominance as an indicator for heath forest disturbance. Environ Sustain Indic. 2020;8(June):0-7.

30. Kirno F, Astiani D, dan EkamawantiHA. Keanekaragaman Jenis tumbuhan paku-pakuan (pteridophyta) dan kondisi tempat tumbuhnya pada hutan ra wa ga mbut sekunder dan la han ga mbut terbuka. J Hutan Lestari. 2019;7(1):11-20.

31. Betty J, Linda R, dan LovadiI. Inventarisa sijenis paku-pakuan (Pteridophyta) terestrial di hutan dusun Tauk kecamatan Air Besar kabupaten Landak. Protobiont. 2015;4(1):94-102.

32. Tjitrosoepomo G. Taksonomi Tumbuhan: Schizophyta, Thallophyta,Bryophyta, Pteridophyta. Yogyakarta: Gajah Mada University Press;

33. Krebs CJ. Ecological Methodology. New York: HarperCollins Publisher; 1989.

34. Bela M, Ayu TMO. I, dan Vera M. Regenerasi hutan gambut pada kawasan lahan gambut bekas terbakardi Desa Pasir dan Desa Sungai Pinyuh, Kabupaten Mempawah, Ka limantan Barat. Pontianak; 2019.

35. Jackson DR and Finley J. Controlling understory fern competition for regeneration success. College of Agricultural Sciences, The Pennsylvania State University. 2016.

36. Yii JE, Bong CF, King JHP, and Jugah, K. Feeding preferences of oil palm pest subterranean 
termite Coptotermes curvignathus (Isoptera: Rhinotermitidae). J. of Ento.2016; 13. 1-10

37. Handayani W and Winara, A. Keanekaragaman makrofauna tanah pada beberapa pengguna an lahan gambut. J. Agroforestri Indonesia. 2020;3(2). $77-88$

38. Dewi FK, Djajakirana G, dan Suwardi. Kelimpahan dan keanekara gaman makrofauna tanah pada tiga pengguna an lahan gambut di Teluk Meranti, Kabupaten Pela lawan, Provinsi Riau. IPB University; 2016.

39. Boror DJ, Triplehorn CA, dan Johnson NF. Pengenalan pelajaran serangga; diterjemahkan oleh S. Partossoedjono. Edisi ke-6. Yogyakarta: UGM Press; 1992.

40. Haneda NF, Retmadhona IY, Nandika D, and Arinana. Biodiversity of subterranean termites on the Acacia crassicarpa plantation. Biodiversitas. 2017;18(4):1657-62.

41. Cheng S, Kirton L., and Gurmit S. Termite attack on oil palm grown o peat soil: identification of pest status and factor contributing to the problem. Planter. 2008;84:200-210.

42. Kirton LG, Brown VK, and Azmi M. The pest status of the termite Coptotermes curvignathus in Acacia mangium plantations: incidence, mode of attack and inherent predisposing factors. J Trop For Sci. 1999;11(4):822-31.

43. Daviyana SA, WardenaarE, and YantiH. Pemanfaatan ekstrak kulit kayu gerunggang (Cratoxylon arborescens) untuk penga wetan kayu karet (Hevea brasiliensis) dari serangan rayap tanah. J Hutan Lestari. 2013;1(2):199-207.

44. Widyastuti R, Santosa DA, dan Djajakirana G. The Diversity and abundance of springtail (collembola) on forests and smallholder in Jambi. J Trop Soils. 2015;20(3):173-80.

45. Yan X, Ni Z, Chang L, Wang K, and Wu D. Soil warming elevates the abundance of collembola in the Songnen plain of China. Sustain. 2015;7(2):1161-71.

46. Verhoef $\mathrm{H}$ and Selm A. Distribution and population dynamics of collembola in relation to soil moisture. Ecography (Cop). 2006 Jun;6:387-8.

47. Gesriantuti N, TrantiatiR, dan Badrun Y. Keanekaragaman serangga permukaan tanah pada lahan gambut bekas kebakaran dan Hutan Lindung Rokan Hulu , Provinsi Riau. J. Phot. 2016;7(1):147-155. 